\title{
Influence of silicon in papaya plant growth
}

\section{Influência do silício no crescimento de plantas de mamoeiro}

\author{
Francico Vanies da Silva SÁ ${ }^{\text {; }}$ Josinaldo Lopes ARAÚJO ${ }^{2}$; Fernando Sarmento de OLIVEIRA ${ }^{3}$; \\ Luderlândio de Andrade SILVA ${ }^{4}$; Romulo Carantino Lucena MOREIRA ${ }^{5}$; \\ Alfredo Nogueira da SILVA NETO ${ }^{6}$
}

${ }^{1}$ Autor para correspondência (Corresponding author); Engenheiro Agronomo; Universidade Federal de Campina
Grande - UFCG; Unidade Acadêmica de Ciências Agrárias - UAGRA; Campus Pombal, Rua Jario Vieira
Feitosa, 1770, Bairro dos Pereiros, CEP 58.840-000, Pombal-PB, Brasil. E-mail:
vanies_agronomia@hotmail.com
2 D. Sc. Professor da Universidade Federal de Campina Grande - UFCG; Unidade Acadêmica de Ciências
Agrárias - UAGRA; Campus Pombal, Email: jhosinal_araujo@yahoo.com.br
${ }^{3}$ Graduando em Agronomia; Universidade Federal de Campina Grande - UFCG; Unidade Acadêmica de
Ciências Agrárias - UAGRA; Campus Pombal, Email: fernandoufcg2010@gmail.com
${ }^{4}$ Graduando em Agronomia; Universidade Federal de Campina Grande - UFCG; Unidade Acadêmica de
Ciências Agrárias - UAGRA; Campus Pombal, Email: luderlandioandrade@gmail.com
5 Graduando em Agronomia; Universidade Federal de Campina Grande - UFCG; Unidade Acadêmica de
Ciências Agrárias - UAGRA; Campus Pombal, Email: romulocarantino@gmail.com
${ }^{6}$ Graduando em Agronomia; Universidade Federal de Campina Grande - UFCG; Unidade Acadêmica de
Ciências Agrárias - UAGRA; Campus Pombal, Email: feumsn@hotmail.com

Recebido em: 12-05-2014; Aceito em: 21-10-2014

\begin{abstract}
Study on the effect of foliar fertilization with silicon on the growth and dry matter accumulation of papaya plants. The experiment was conducted under greenhouse conditions from December 2012 to March 2013. The treatments consisted of five concentrations of silicon (0 (control); $1 ; 2 ; 3$ and $4 \mathrm{~mL} \mathrm{~L}^{-1}$ ) applied to papaya leaves in a completely randomized design and four replications, totaling 20 experimental units. The genotype of papaya Tainung-1 (Formosa group) was used, which was grown for 90 days after sowing and received three foliar fertilization with silicon at 45,60 and 75 days after sowing. Foliar fertilization with potassium silicate concentrations resulted in papaya plants more vigorous, with less stress to biotic and abiotic factors in this experiment. The concentration of $2.2 \mathrm{~mL} \mathrm{~L}^{-1}$ silicon on average promoted better growth and dry matter accumulation in roots of papaya plants.
\end{abstract}

Additional keywords: Carica papaya L.; dry matter; mineral nutrition.

\begin{abstract}
Resumo
Objetivou-se avaliar o efeito da adubação com silício via foliar no crescimento inicial e acúmulo de massa seca de plantas de mamoeiro. O experimento foi realizado em ambiente protegido no período de dezembro de 2012 a março de 2013. Os tratamentos constituíram-se de cinco concentrações de silício (0 (controle); $1 ; 2 ; 3$ e $4 \mathrm{~mL} \mathrm{~L}^{-1}$ ) aplicadas via foliar ao mamoeiro, em delineamento experimental inteiramente casualizado, com quatro repetições totalizando 20 unidades experimentais. $O$ genótipo de mamoeiro utilizado foi o híbrido Tainung-1, grupo Formosa, o qual foi cultivado durante 90 dias após a semeadura e recebeu três adubações foliares com silício aos 45, 60 e 75 dias após a semeadura. A adubação foliar com concentrações de silicato de potássio resultou em plantas de mamoeiro mais vigorosas, com menor estresse aos fatores bióticos e abióticos neste experimento. A concentração de $2,2 \mathrm{~mL} \mathrm{~L}^{-1}$ de silício em média, proporcionou maior crescimento e acúmulo de massa seca nas raízes das plantas de mamoeiro.
\end{abstract}

Palavras-chave adicionais: Carica papaya L.; massa seca; nutrição mineral.

\section{Introduction}

The papaya tree (Carica papaya L.) is a tropical plant, herbaceous, and with high productivity and fruit quality. In the last decade this culture achieved great economic and social expression in Brazil, with emphasis on the states of Bahia, Espirito Santo, Ceará and Rio Grande do Norte, which together represent $87 \%$ of national production (IBGE, 2014). In the World ranking, Brazil is the second largest papaya producer, accounting for $12.2 \%$ of production, and the third largest exporter. In 2012, 1.517.696 tons of fruit were produced in a havested area of 31.310 ha (FAO, 2014).

Papaya stands out in the national fruit production for its high acceptance by the consumer 
market for in natura and processed into jellies and candy fruit consumption, given that it is a rich source of vitamin A and papain, a protein that helps to improve human digestive process (MANICA, 2006). In addition, the constant need for orchards renewal in the period of 2.5 to 4 years provides employment and income in producing areas (CANESIN \& CORRÊA, 2006; DANTAS et al., 2002).

The initial growth phase is of vital importance for the success of an agricultural exploration. Nutritionally balanced papaya plants at this stage allow a better performance of the orchards in the field, with a higher number of production cycles per year. Thus, there is the need to use vigorous plants with good architecture and well-developed roots, in order to provide a further plant development and resistance to stress during the production process, since the initial plant growth is directly related with precocity and fruit production (TRINDADE et al., 2000).

The foliar fertilization with soluble liquid silicon sources ( $\mathrm{Si}$ ) has been the focus of several studies. The efficiency and convenience of its use have shown promising results in several crops, including those which do not accumulate this element, such as coffee, soybeans, lettuce and cotton (REIS et al., 2007). Si application through leaves also helps in disease control, as observed by PRATISSOLI et al. (2007), where silicon sources application through leaves reduced the incidence, and especially the severity, of papaya black spot (Asperisporium caricae). However, reports of silicon effect on the growth of papaya plants are almost non-existent.

Despite this element neglect in Brazilian agriculture, several studies have shown the beneficial effects of its application in accumulating species, such as rice (MA et al., 2001), sugar cane (MORAES et al., 2011), corn (SOUSA et al., 2010) and grasses (SÁVIO et al., 2011). However, dicotyledonous plants, considered not accumulative, such as: lettuce (RESENDE et al., 2007), tomato (EMRICH et al., 2011), coffee (REIS et al., 2008), strawberry (FIGUEIREDO et al., 2010), potato (SILVA et al., 2010), cocoa (PINTO et al., 2012), beans, soybean and peanut (CRUSCIOL et al., 2013) have also found beneficial answers to Si application.

However, silicon ( $\mathrm{Si}$ is considered somewhat movable in plants (MA et al., 2001; KORNDÖRFER et al., 2002). Thus, Si supply through foliar fertilization can facilitate the absorption of this element in the plants shoots and, therefore, promote photosynthetic activity, due to its influence on chlorophyll content (EPSTEIN \& BLOOM, 2006; EMRICH et al., 2011). The purpose of research on Si leaf supply is to find viable alternatives of fertilization with this beneficial element. Moreover, not accumu- lating plants, such as papaya, absorbs Si more slowly, thus requiring appropriate Si concentrations that will allow the best use by the plant.

$\mathrm{Si}$ beneficial effect in phytomass accumulation in cultivated plants is associated with alterations in the plant structure, allowing, for example, to better capture solar energy and reduce lodging. Although plant metabolism essentiality is still unknown (EPSTEIN \& BLOOM, 2006), Si has a role in defense molecules synthesis when solubilized in the plant (PRATISSOLI et al., 2007; SILVA et al., 2010; PINTO et al., 2012). Besides that, Si provides: improvement in plant architecture, making it more upright and thus reducing its shading; reduction in transpiration; increasing in cells mechanical resistance; higher plant resistance to attack by insects and diseases (EPSTEIN \& BLOOM, 2006;PRATISSOLI et al., 2007; SILVA et al., 2010; SOUSA et al., 2010).

Based on the above, the objective of this study was to evaluate the effect of foliar fertilization with potassium silicate in the initial growth and in dry matter accumulation of papaya plants.

\section{Material and methods}

The experiment was conducted in a greenhouse, from December 2012 to March 2013, in the municipality of Pombal/PB, with geographic coordinates of $6^{\circ} 46^{\prime} 13^{\prime \prime}$ south latitude and $37^{\circ} 48^{\prime}$ 06" Iongitude west of Greenwich. According to Köppen classification, the local climate is classified as semi-arid ("Aw" hot and humid).

The treatments consisted of five silicon concentrations ( 0 (control), 1, 2, 3 and $4 \mathrm{~mL} \mathrm{~L}^{-1}$ ), applied in the papaya through the leaves in a completely randomized design with four replications, totaling 20 experimental units. The concentrations studied were based on the recommendation of the product by agriculture, given that this product has not been studied yet in papaya crop for initial growth purposes.

Papaya genotype used was Tainung-1 hybrid, framed in the "Formosa" group. The seeds were sown in pots with a capacity of three liters of soil. The soil used (Table 1) was removed from the research area at a $0-20 \mathrm{~cm}$ layer and is classified as a Fluvisol of sandy loam texture (EMBRAPA, 2006), which was duly fertilized following MALAVOLTA (1987) recommendations, with installment in two and three times to potassium and nitrogen, respectively (Table 2). With respect to calcium and sulfur, sources were not used to supply them, as they were already contained in the single superphosphate, a rich source in these nutrients and phosphorus (Table 2). With the exception of the single superphosphate, all fertilizers/chemicals were applied as a solution. 
Table 1 - Analysis of chemical and physical properties of the soil used in the experiment.

\begin{tabular}{lccc}
\hline Chemical properties & Value & Physical properties & Value \\
\hline $\mathrm{pH}\left(\mathrm{CaCl}_{2}\right)$ & 6.70 & Sand $\left(\mathrm{g} \mathrm{kg}^{-1}\right)$ & 716.00 \\
$\mathrm{P}\left(\mathrm{mg} \mathrm{kg}^{-1}\right)$ & 6.00 & Silt $\left(\mathrm{g} \mathrm{kg}^{-1}\right)$ & 159.00 \\
$\mathrm{~K}^{+}\left(\mathrm{cmol}_{\mathrm{c}} \mathrm{dm}^{-3}\right)$ & 0.22 & Clay $\left(\mathrm{g} \mathrm{kg}^{-1}\right)$ & 125.00 \\
$\mathrm{Na}^{+}\left(\mathrm{cmol}_{\mathrm{c}} \mathrm{dm}^{-3}\right)$ & 0.11 & Ds $\left(\mathrm{g} \mathrm{cm}^{-3}\right)$ & 1.43 \\
$\mathrm{Ca}^{2+}\left(\mathrm{cmol}_{\mathrm{c}} \mathrm{dm}^{-3}\right)$ & 4.70 & $\mathrm{Dp}\left(\mathrm{g} \mathrm{cm}^{-3}\right)$ & 2.61 \\
$\mathrm{Mg}^{2+}\left(\mathrm{cmol}_{\mathrm{c}} \mathrm{dm}^{-3}\right)$ & 2.30 & Porosity $\left(\mathrm{m}^{3} \mathrm{~m}^{-3}\right)$ & 0.45 \\
$\mathrm{H}+\mathrm{Al}\left(\mathrm{cmol}_{\mathrm{c}} \mathrm{dm}^{-3}\right)$ & 2.30 & Textural class & Sandy loam \\
$\mathrm{SB}\left(\mathrm{cmol}_{\mathrm{c}} \mathrm{dm}^{-3}\right)$ & 7.20 & Soil Tension $(\mathrm{MPa})$ & Water content $\left(\mathrm{g} \mathrm{kg}^{-1}\right)$ \\
$\mathrm{CTC}\left(\mathrm{cmol}_{\mathrm{c}} \mathrm{dm}^{-3}\right)$ & 9.60 & 0.01 & 115.00 \\
$\mathrm{M} . \mathrm{O}\left(\mathrm{g} \mathrm{kg}^{-1}\right)$ & 11.00 & 0.033 & 91.00 \\
$\mathrm{~V}(\%)$ & 74.90 & 1.5 & 52.00 \\
$\mathrm{PST}(\%)$ & 1.10 & & \\
$\left.\mathrm{Al}\right|^{3+}\left(\mathrm{cmol}_{\mathrm{c}} \mathrm{dm}^{-3}\right)$ & 0.00 & Available Water $\left(\mathrm{g} \mathrm{kg}^{-1}\right)$ & 63.00 \\
\hline
\end{tabular}

$\mathrm{SB}=$ sum of bases; $\mathrm{CTC}=$ cation exchange capacity; $\mathrm{V}=$ base saturation; $\mathrm{PST}=$ Sodium saturation percentage; $\mathrm{M} . \mathrm{O}=\mathrm{Organic}$ matter.

The initial application of the treatments was performed 45 days after sowing, when the plants had enough leaf area to receive foliar fertilization. Plants received three foliar applications with silicon, arranged every 15 days until 75 days after sowing (Table 3 ). The silicon source was the commercial soluble potassium silicate Quimifol Silicio $\AA$, with $1.31 \mathrm{~kg} \mathrm{~L}^{-1}$ density and containing $10 \%$ Si and $8.3 \%$ potassium $\left(\mathrm{K}^{+}\right)$.

The potassium concentration in the applied solutions were equal, therefore, potassium chloride was added (KCL) to balance the potassium levels arising from the potassium silicate solution (SiK) (Table 3). Along with the solution an adjuvant and an adhesive were added: Adesil $\AA$ at a concentration of $0.1 \mathrm{~mL} \mathrm{~L}^{-1}$, as recommended by the manufacturer. Spraying was performed with a manual pressure spray
Pralik AGRO ${ }^{\circledR}$ with $1.5 \mathrm{~L}$ capacity syrup, done in the evening to minimize evaporation losses, in the proportion of $50 \mathrm{~mL}$ syrup per experimental unit, covering up the soil with a plastic bag, in order to ensure that the solution sprayed on the leaf surface would have no contact with it.

During the experiment, air temperature and humidity data were monitored with the aid of a digital thermo-hygrometer inside the greenhouse (Table 4).

At 90 days after sowing were evaluated: plant height (AP) $(\mathrm{cm})$, using a graduated scale, through the distance between the ground and the plants top; stem diameter (DC) (mm), using a digital pachymeter, measured $2 \mathrm{~cm}$ from the ground, and the number of leaves (NF), through the count of mature leaves.

Table 2 - Description of fertilization according to the nutrients, doses and characteristics of sources used in soil fertilization for papaya plants growing in pots..

\begin{tabular}{lccr}
\hline Nutrients & Concentrations (ppm) & Sources & $\%$ of Nutrient \\
\hline $\mathrm{N}$ & 210.0 & Urea & 45.00 \\
$\mathrm{P}$ & 250.0 & Single Superphosphate & 7.74 \\
$\mathrm{~K}$ & 150.0 & Potassium Chloride & 52.00 \\
$\mathrm{Ca}$ & 581.0 & Single Superphosphate & 18.00 \\
$\mathrm{Mg}$ & 50.0 & Hexahydrate Magnesium Chloride & 11.90 \\
$\mathrm{~S}$ & 323.0 & Single Superphosphate & 10.00 \\
$\mathrm{~B}$ & 0.6 & Boric Acid & 17.50 \\
$\mathrm{Mn}$ & 4.0 & Monohydrate Manganese Sulfate & 32.50 \\
$\mathrm{Fe}$ & 5.0 & Fe-EDTA & 5.00 \\
$\mathrm{Mo}$ & 0.1 & Tetrahydrate Ammonium Molybdate & 54.30 \\
$\mathrm{Zn}$ & 5.0 & Heptahydrate Zinc Sulfate & 22.70 \\
$\mathrm{Cu}$ & 1.3 & Pentahydrate Copper Sulfate II & 25.40 \\
\hline
\end{tabular}


Tabela 3 - Amounts of silicon (Si) and potassium (K) applied through foliar fertilization with potassium silicate $(\mathrm{SiK})$ and potassium chloride $(\mathrm{KCl})$ in the studied treatments.

\begin{tabular}{|c|c|c|c|c|c|c|c|c|c|c|c|}
\hline \multirow{3}{*}{$\begin{array}{c}\mathrm{Si} \\
\text { Concentrations } \\
\left(\mathrm{mL} \mathrm{L}^{-1}\right)\end{array}$} & \multicolumn{3}{|c|}{ First application } & \multicolumn{3}{|c|}{ Second Application } & \multicolumn{3}{|c|}{ Third Application } & \multicolumn{2}{|c|}{ Total } \\
\hline & Si(mg) & & & Si(mg) & & & $\mathrm{Si}(\mathrm{mg})$ & & & & $1 \mathrm{~m}$ \\
\hline & SiK & SiK & $\mathrm{KCl}$ & SiK & SiK & $\mathrm{KCl}$ & SiK & SiK & $\mathrm{KCl}$ & Sl(mg) & $\mathrm{K}(\mathrm{mg})$ \\
\hline 0 & 0 & 0 & 436 & 0 & 0 & 436 & 0 & 0 & 436 & 0 & 1308 \\
\hline 1 & 131 & 109 & 327 & 131 & 109 & 327 & 131 & 109 & 327 & 327 & 1308 \\
\hline 2 & 262 & 218 & 218 & 262 & 218 & 218 & 262 & 218 & 218 & 786 & 1308 \\
\hline 3 & 393 & 327 & 109 & 393 & 327 & 109 & 393 & 327 & 109 & 1179 & 1308 \\
\hline 4 & 524 & 436 & 0 & 524 & 436 & 0 & 524 & 436 & 0 & 1572 & 1308 \\
\hline
\end{tabular}

Table 4 - Monthly average air temperature and humidity measured over the period of the experiment inside the greenhouse.

\begin{tabular}{lcc}
\hline Months & Temperature $\left({ }^{\circ} \mathrm{C}\right)$ & Humidity $(\%)$ \\
\hline December & 38 & 42 \\
January & 32 & 45 \\
February & 35 & 48 \\
March & 36 & 46 \\
\hline
\end{tabular}

Also with regard to the first reading, the total gain of the leaf area $(\mathrm{LA})\left(\mathrm{cm}^{2}\right)$ was determined using the equation proposed by ALVES \& SANTOS (2002), from the measurement of the leaf width (L), as described in equation 1 . It has been converted to square meter $\left(\mathrm{m}^{2}\right)$ afterwards.

$L A=0.0859 \times L^{2.7385}$

Where $L A$ is the leaf area, in $\mathrm{m}^{2}$, and $L$ is the leaf width, in $\mathrm{m}$.

After the last growth analysis, 90 days after sowing, the shoot part dry matter (SDM) (g), root dry matter (RDM) (g) and total dry matter
(TDM) (g) were obtained through material collection, by separating shoots and roots, in which the appropriate parts were packed in an air circulation oven $\left( \pm 65^{\circ} \mathrm{C}\right)$ for 72 hours, until the material reached a constant weight, and then were subsequently weighed in an analytical balance with 0.0001 precision.

The variables were subjected to analysis of variance ( $F$ test), at $5 \%$ probability level, and polynomial regression analysis, with the evaluation of the linear and quadratic effects through the Sisvar software (FERREIRA, 2011).

\section{Results and discussions}

The growth variables: height and number of leaves of papaya plants were significantly influenced the in $5 \%$ probability level, according to the foliar fertilization with silicon. However, stem diameter and leaf area were not affected $(p<0.05)$ by silicon foliar application (Table 5$)$.

Table 5 - Analysis of variance of the variables, time (AT), stem diameter (SD), number of leaves (NL) and leaf area (LA) of papaya plants fertilized with different concentrations of silicon through foliar application.

\begin{tabular}{lccccc}
\hline \multirow{2}{*}{ FV } & \multirow{2}{*}{$\mathrm{GL}$} & \multicolumn{5}{c}{ Mean Square } \\
\cline { 3 - 6 } & & $\mathrm{AT}$ & $\mathrm{SD}$ & $\mathrm{NL}$ & $\mathrm{LA}$ \\
\hline Concentrations & 4 & $18.19^{*}$ & $1.29^{\text {ns }}$ & $2.82^{*}$ & $0.003^{\text {ns }}$ \\
Error & 12 & 7.56 & 3.09 & 1.81 & 0.005 \\
\hline CV $(\%)$ & & 8.98 & 14.26 & 14.73 & 31.50 \\
\hline Linear Equations & & ${ }^{\mathrm{ns}}$ & ${ }^{\mathrm{ns}}$ & ${ }^{\mathrm{ns}}$ & ${ }^{\mathrm{ns}}$ \\
\hline Quadratic Equations & & ${ }^{*}$ & ${ }^{\mathrm{ns}}$ & ${ }^{*}$ & ${ }^{\mathrm{ns}}$ \\
\hline
\end{tabular}

FV-Variation Sources; GL - Degree of Freedom; Significant at $0.5\left(^{*}\right)$ and at $0.01\left(^{* *}\right)$ probability; (ns) not significant; CV - Coefficient of variation.

There was an effect of silicon concentrations on growth in height $(\mathrm{cm})$ of papaya plants (Figure 1A). It was observed for plant height, which when treated with increasing concentrations of silicon had a quadratic response, obtaining with a $2.41 \mathrm{~mL} \mathrm{~L}^{-1}$ silicon concentration the estimated value of $32.36 \mathrm{~cm}$, an increase of $16.8 \%$ in comparison with plants that received no foliar fertilization (control). It was also recorded to the highest silicon concentrations a significant reduction in the height of papaya plants (Figure 1A).

The silicon concentrations have not influenced the growth in the stem diameter of papaya plants. According to ZUBA JUNIOR et al. (2011), the beneficial effects of silicate fertilization in the early stage of plant growth is correlated to the existing quantities of this element in the soil, which may be sufficient to meet the needs of the plants at an early stage since, with respect to silicon, there are still questions about its effects on non- 
accumulating species. However, despite the beneficial effects of silicon be attributed mainly to accumulating plants, studies have observed beneficial effects of this element in nonaccumulating plants, when it is related to higher plant resistance against attacks by insects or diseases, with papaya as an example (PRATISSOLI et al., 2007; SILVA et al., 2010; SOUSA et al., 2010).

Regarding leaves number, papaya leaves emission quadratic response was recorded in function of increasing silicon concentrations, with the maximum value obtained at a concentration of $1.97 \mathrm{~mL} \mathrm{~L}^{-1}$ silicon, estimated at 10 leaves (Figure 1B). The number of leaves increase obtained in this treatment was of approximately $19.3 \%$, compared to the control. Concentrations higher than $1.97 \mathrm{~mL} \mathrm{~L}^{-1}$ resulted in a significant reduction in the number of leaves (Figure 1B). The leaves are the organs responsible for photosynthesis in plants and produce over $90 \%$ of plant carbohydrates (TAIZ \& ZEIGER, 2013), thus reductions in the leaves number can influence the dry matter accumulation in vegetables. This fact was not verified in this experiment, so that the increase in the number of leaves had no effect on leaf area and shoot dry matter of papaya plants (Tables 5 and 6 ). Believing that with this fact silicon foliar application stimulated leaves emission in papaya plants, although with reduced leaf blades, minimizing water loss by perspiration due to the high temperatures and low relative humidity recorded along the experiment (Table 4). The silicon accumulation in perspiration organs causes the formation of a silica cuticle double layer, which reduces water loss through transpiration, increasing the efficiency of water usage by the plant (NWUGO \& HUERTA, 2008).

There were significant effects $(p<0.05)$ to the roots dry matter and total dry matter of papaya plants in function of foliar fertilization with silicon. However, significant effects for shoots dry matter were not found (Table 6).

The silicon fertilization did not influence papaya shoots dry matter accumulation, resulting possibly from the lower thickening and expansion of the leaf blade, as well as cell swelling due to the reduction of heat stress occurred in the smaller silicon concentrations applied (TAIZ \& ZAIGER, 2013).
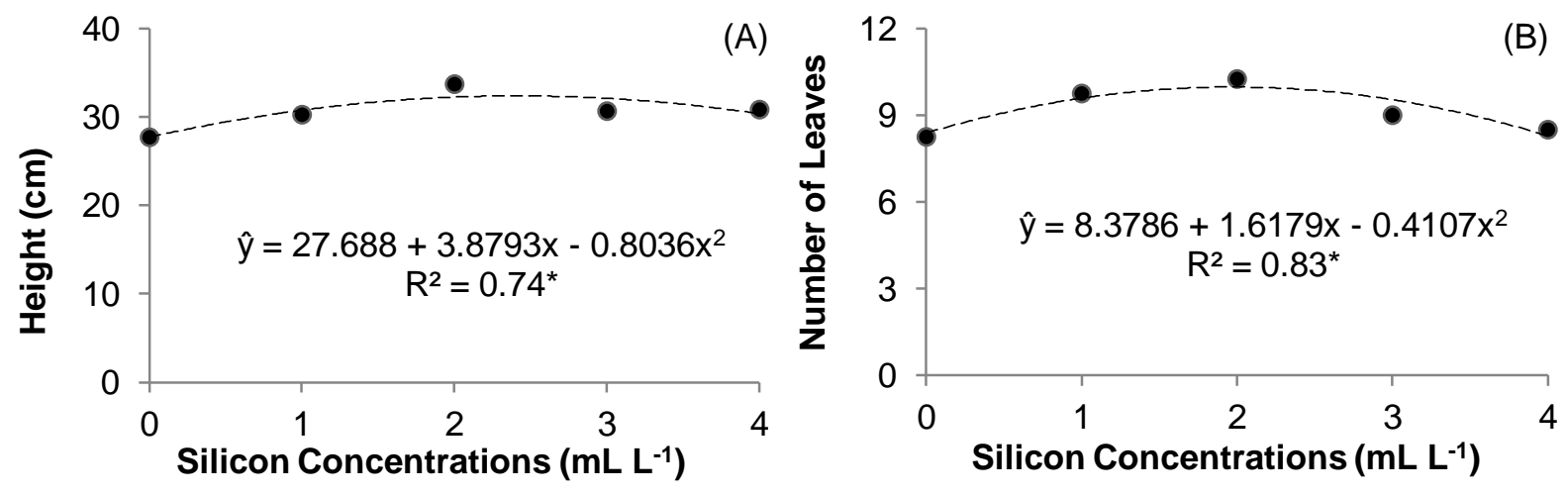

Figure 1 - Height and number of leaves of papaya plants in function of foliar fertilization with increasing concentrations of silicon.

Table 6 - Analysisof variance of the variables shoot dry matter (SDM), root dry matter (RDM) and total dry matter (TDM) of papaya plants fertilized with different concentrations of silicon foliar.

\begin{tabular}{lcccc}
\hline FV & \multirow{2}{*}{ GL } & \multicolumn{3}{c}{ Mean Square } \\
\cline { 3 - 5 } & 4 & SDM & RDM & TDM \\
\hline Concentrations & $4.31^{\text {ns }}$ & $13.22^{*}$ & $39.10^{*}$ \\
Error & 12 & 4.00 & 4.46 & 9.64 \\
\hline CV (\%) & & 15.68 & 23.10 & 14.17 \\
\hline Linear Equations & & ns & ns & $*$ \\
Quadratic Equations & & ns & ${ }^{* *}$ & ${ }^{* *}$ \\
\hline
\end{tabular}

FV-Sources of Variation; GL - degree of freedom; Significant at $0.5\left(^{*}\right)$ and $0.01\left(^{* *}\right)$ probability, (ns) not significant, CV - Coefficient of variation.

It was discovered that there was a higher accumulation of root dry matter (11.49 g) when papaya plants were fertilized with a concentration of $2.24 \mathrm{~mL} \mathrm{~L}^{-1}$ silicon, where concentrations above this number promoted reductions in roots dry matter accumulation (Figure 2A), as it was 
checked for growth in height and leaves number of papaya plants. This effect may be related to climate conditions in the environment where the experiment was conducted, due to high temperatures and low relative humidity. Thus, the silicon concentrations influenced in the reduction of leaf blades from papaya plants, and also encouraged roots further development, as more water and nutrients were necessary to compensate for perspiration losses and help plant growth. It must be considered that Si can stimulate growth and dry matter accumulation indirectly, as it influences chlorophyll content (EPSTEIN \& BLOOM, 2006; EMRICH et al., 2011) and thus influences the photosynthetic potential of plants.

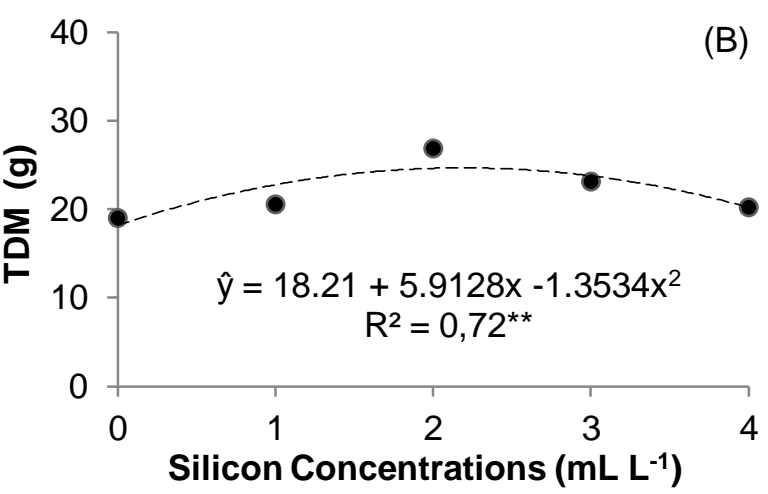

Figure 2 - Root (RDM) and total dry matter (TDM) of papaya plants due to foliar fertilization with increasing concentrations of silicon mass.

For the total dry matter, quadratic response was noted in function of the increase in applied silicon concentrations, reaching a peak of $24.67 \mathrm{~g}$ in the concentration of $2.18 \mathrm{~mL} \mathrm{~L}^{-1}$ silicon. Concentrations higher than $2.18 \mathrm{~mL} \mathrm{~L}^{-1}$ reduced the total dry matter accumulation by plants (Figure 2B). It is believed that the increase in leaf number and in root dry matter has influenced directly to a higher papaya plants total dry matter.

\section{Conclusions}

Foliar fertilization with potassium silicate concentrations resulted in papaya plants more vigorous, with less stress to biotic and abiotic factors in this experiment.

The concentration of $2.2 \mathrm{~mL} \mathrm{~L}^{-1}$ silicon on average promoted better growth and dry matter accumulation in roots of papaya plants.

\section{References}

ALVES, A. A. C.; SANTOS, E.L. Estimativa da área foliar do mamoeiro utilizando medidas da folha. In: CONGRESSO BRASILEIRO DE FRUTICULTURA, 17, 2002, Belém. Anais.... Belém: CBF, 2002. CDROM.

CANESIN, R. C. F. S.; CORRÊA, L. S. Uso de esterco associado à adubação mineral na produção de mudas de mamoeiro (Carica papaya L.). Revista Brasileira de Fruticultura, Jaboticabal, v.28, n.3, p.481-486, dez. 2006.

CRUSCIOL, C. A. C.; SORATTO, R. P.; CASTRO, G. S. A.; COSTA, C. H. M.; FERRARI NETO, J. Aplicação foliar de ácido silícico estabilizado na soja, feijão e amendoim. Revista Ciência Agronômica, Fortaleza, v.44, n.2, p.404-410, 2013.
DANTAS, J. L. L.; DANTAS, A. C. V. L.; LIMA, J. F. Mamoeiro. In: BRUCKNER, C.H. Melhoramento de fruteiras tropicais. Viçosa: UFV, 2002. p. 309-349.

EMBRAPA. Empresa Brasileira de Pesquisa Agropecuária. Centro Nacional de Pesquisa de Solos. Sistema brasileiro de classificação de solos. 2.ed. Rio de Janeiro, 2006. 212p.

EMRICH, E.B.; SOUZA, R. J.; LIMA, A. A.; FIGUEIREDO, F. C.; SILVA, D. R. G.Cultivo do tomateiro em substratos orgânicos sob aplicação foliar de silicato de potássio em ambiente protegido. Ciência e Agrotecnologia, Lavras, v. 35, n.1, p. 56-61, 2011.

EPSTEIN, E.; BLOOM, A. J. Nutrição mineral de plantas: princípios e perspectivas. 2.ed. Londrina: Editora Planta, 2006. 403p.

FAO. Food and Agriculture Organization of the United Nations. FAOSTAT. Disponível em: <http://faostat3.fao.org/faostat-gate-

way/go/to/download/Q/QC/S>. 25.ago.2014.

FERREIRA, D. F. Sisvar: a computer statistical analysis system. Ciência Agrotecnologia, Lavras, v.35, n.6, p.1039-1042, 2011.

FIGUEIREDO, F. C.; BOTREL, P. P.; TEIXERA, C. P.; PETRAZZINI, L. L.; LOCARNO, M.; CARVALHO, J. G. Pulverização foliar e fertirrigação com silício nos atributos físico-químicos de qualidade e índices de coloração do morango. Ciência e Agrotecnologia, Lavras, v.34, n.5, p.1306-1311, 2010. 
IBGE. Instituto Brasileiro de Geografia e Estatística. Séries históricas e estatísticas. Disponível: <http://www.ibge.gov.br/home/download/estatistica.shtm>. Acesso em: 26 ago. 2014.

KORNDÖRFER, G. H.; PEREIRA, H. S.; CAMARGO, M. S. Papel do silício na produção de cana-de-açúcar. Revista STAB, Piracicaba, 21, n.2, p.6-9, 2002.

MA, J. F.; MIYAKE, Y.; TAKAHASHI, E. Silicon as a beneficial element for crop plants. In: DATNOFF, L. E.; SNYDER, G. H.; KORNDÖRFER, G. H.(Ed.). Silicon in agriculture. Amsterdam: Elsevier, 2001. p.17-39.

MALAVOLTA, E. Manual de calagem e adubação das principais culturas. São Paulo, Ceres, 1987.496p.

MANICA, I. Cultivares e melhoramentos. In: MANICA, I.; MARTINS, D. S.; VENTURA, J. A (Ed.). Mamão: tecnologia de produção póscolheita, exportação, mercados. Porto Alegre RS: Cinco continentes, 2006. p.49-82.

MORAES, W. B.; JESUS JUNIOR, W. C; MORAES, W. B.; ARAUJO, G. L.; SOUZA, A. F.; SILVA, M. V. Aplicação de silicato de potássio e crescimento foliar da cana-de-açúcar. Revista Brasileira de Ciências Agrárias, Recife, v.6, n.1, p.59-64, 2011.

NWUGO, C. C.; HUERTA, A. J. Effects of silicon nutrition on cadmium-uptake, growth andpho to synthesis of rice (Oryza sativa L.) seedlings exposed to long-term low level cadmium. Plant and Soil, Dordrecht, v.311, n.1-2, p.73-86, 2008.

PINTO, D. G.; AGUILAR, M. A. G.; SOUZA, C. A. S.; SILVA, D. M.; SIQUEIRA, P. R.; CAO, J. R.; ZANETTI, L. V. Alterações fisiológicas após aplicação de silício em cacau e sua influência na preferência por pulgões. Revista Ceres, Viçosa, v.59, n.3, p.360-367, 2012.

PRATISSOLI, D.; ALMEIDA, G. D.; JESUS JÚNIOR, W. C.; VICENTINI, V. B.; HOLTZ, A. M.; COCHETO, J. G. Fertilizante organomineral e argila silicatada como indutores de resistência á varíola do mamoeiro. Idesia, Arica, v.25, n.2, p.6367, 2007.
REIS, T. H. P.; FIGUEIREDO, F. C.; GUIMARÃES, P. T. G.; BOTREL, P. P.; RODRIGUES, C. R. Efeito da associação silício líquido solúvel com fungicida no controle fitossanitário do cafeeiro. Coffee Science, Lavras, v.3, n.1, p.78-80, 2008.

REIS, T. H. P.; GUIMARÃES, P. T. G.; FIGUEIREDO, F. C.; POZZA, A. A. A.; NOGUEIRA, F. D.; RODRIGUES, C. R. O silício na nutrição e defesa de plantas. Belo Horizonte: EPAMIG, 2007. 124p. (Boletim Técnico, 82).

RESENDE, G. M.; YURI, J. E.; SOUZA, R. J. Épocas de plantio e doses de silício no rendimento de alface tipo americana. Horticultura Brasileira, Brasília, v.25, n.3, p.455-459, 2007.

SÁVIO, F. L.; SILVA, G. C.; TEIXEIRA, I. R.; BORÉM, A. Produção de biomassa e conteúdo de silício em gramíneas forrageiras sob diferentes fontes de silicato. Semina: ciências agrárias, Londrina, v.32, n.1, p.103-110, 2011.

SILVA, V. F.; MORAES, J. C.; MELO, B. A. Fontes de silício na indução de resistência a insetospraga e no desenvolvimento de plantas de batata inglesa. Revista Brasileira de Agroecologia, Porto Alegre, v.5, n.2, p.149-156, 2010.

SOUSA, J. V.; RODRIGUES, C. R.; LUZ, J. M. Q.; SOUSA, V. B. F.; CARVALHO, P. C.; RODRIGUES, T. M.; BRITO, C. H. Silicato de potássio via foliar no milho: fotossíntese, crescimento e produtividade. Bioscience Journal, Uberlândia, v.26, n.4, p.502-513, 2010.

TAIZ, L.; ZEIGER, E. Fisiologia vegetal. 5.ed. Porto Alegre: Artmed. 2013. 918p.

TRINDADE, A. V.; FARIA, N. G.; ALMEIDA, F. $P$.Uso de esterco no desenvolvimento de mudas de mamoeiro colonizados com fungos micorrízicos. Pesquisa Agropecuária Brasileira, Brasília, v.35, n.7, p.1389-1394, 2000.

ZUBA JUNIOR, G. R.; SAMPAIO, R. A.; NASCIMENTO, A. L.; LIMA, N. N.; FERNANDES, L. A.Crescimento inicial de mamoneira adubada com lodo de esgoto e silicato de cálcio e magnésio. Revista Caatinga, Mossoró, v.24, n.4, p.157-163, 2011. 